\title{
RHEOLOGICAL CHARACTERIZATION OF COMMERCIAL SWEETENED CONDENSED MILK
}

\author{
AFONSO MOTA RAMOS * \\ ANDERSON NASCIMENTO DE OLIVEIRA ** \\ MANOELA MACIEL S. DIAS *** \\ ERICK ORNELLAS NEVES ****
}

\begin{abstract}
The present study have analyzed samples of sweetened condensed milk of five brands sold in the Brazilian market regarding their rheological behavior and viscoelasticity. The products presented pseudoplastic fluid behavior, illustrated by the experimental data of shear stress versus strain rate, with adjustments made to fit the Power Law and Casson models. The effect of temperature on apparent viscosity of the products followed the Arrhenius model, with activation energy values ranging from 33.8 to $40.9 \mathrm{~kJ} \mathrm{~mol}^{-1}$. The products showed loss modulus (G") greater than storage modulus $\left(G^{\prime}\right)$, indicating a semi-liquid material behavior.
\end{abstract}

* DSc - Food Science and Technology, Food Technology Department, Universidade Federal de Viçosa (UFV), Viçosa, MG, Brazil (e-mail: amramos@ufv.br).

** DSc - Food Science and Technology, Food Engineering Department, Universidade Federal do Espírito Santo (UFES), Alegre, ES, Brazil (e-mail: anderson.n.oliveira@ufes.br).

** DSc - Food Science and Technology, Food Technology Department, UFV, Viçosa, MG, Brazil (e-mail: manoelamaciel810@gmail.com).

**** MSc - Food Science and Technology, Food Engineering Department, Universidade Federal de São João del Rei (UFSJ), Sete Lagoas, MG, Brazil (e-mail: neves@ufsj.edu.br). 


\section{INTRODUCTION}

Sweetened condensed milk is an ingredient used in Brazilian cuisine obtained by partial removal of water from milk and the addition of sugar. Although this product is made by different processes, each results in viscous products with smooth texture, slightly brown color and each should have a certain composition in milk fat, milk solids and milk protein in nonfat solids (FAO/WHO, 2012; TAMIME, 2009). In Brazil, there is no specific legislation for the product, which is usually made of milk, sugar and lactose.

Operations of heat treatment, homogenization, vacuum evaporation, seeding and packaging are carried out during sweetened condensed milk processing. Generally, the rheological behavior of sweetened condensed milk is affected by factors such as increased interaction of protein micelles, total solid content, time/temperature history of the product, pre-heat treatment and chemical composition (BIENVENUE, JIMÉNEZ-FLORES \& SINGH, 2003).

The acceptability of sweetened condensed milk by consumers depends greatly on the sensory properties of the product, among which, viscosity is considered the key quality parameter (TAMIME, 2009). Thus, to achieve optimal viscosity for consumer acceptance, rheological properties are used to control process conditions to achieve a product whose quality will meet consumer standards (OZER et al., 1998). Moreover, these properties give important insight into the structural organization of food and play an important role in heat transfer (AHMED \& RAMASWAMY, 2006).

The rheological behavior of fluids can be described with the help of various mathematical models, while the most appropriate model depends on the characteristic of each fluid. The OstwaldDe Waele, Herschel-Bulkley and Casson models are used with non-Newtonian fluids and describe the behavior of food products very well (SCHRAMM, 2006; STEFFE, 1996). Many semi-solid foods are viscoelastic materials, which blend properties of viscous fluids and elastic solids. These properties are observed by small amplitude (dynamic) oscillatory tests, keeping the product structure intact. These tests can be used to relate dynamic rheological parameters with the molecular structure of the sample and the glass transition temperatures, which are important in the characterization of real materials (GUNASEKARAN \& AK, 2000).

The lack of standards of identity and quality for sweetened condensed milk in Brazil has lead to products with very different characteristics, such as color, texture, viscosity. Thus, rheological property characterization is useful for quality control, standardization of product and it can be used to set a standard of identity for the marketed products.

The objective of this study was to characterize the sweetened condensed milk of five commercial trademarks that represent the Brazilian market with respect to flow curves and viscoelastic properties.

\section{MATERIAL AND METHODS}

Samples of sweetened condensed milk of five brands representative of the Brazilian market (A, B, C, D and E) were purchased at local supermarkets in Juiz de Fora (MG), Brazil. Samples from three different lots per branch were purchased, which constituted the repetitions of the experiment. The samples of different brands had close manufacturing dates to avoid possible effects of time on the results.

\subsection{FLOW BEHAVIOR}

Rheological analyses were carried out in a Brookfield concentric cylinder rheometer, Searle type, model R/S SST Plus 2000, equipped with a thermostatic bath to control the temperature of the sample. CC-14 was the measurement sensor, with strain rate ranging from 7.7 to $300 \mathrm{~s}^{-1}$.

The experiments were performed at temperatures of $5,15,25,35,45$ and $55^{\circ} \mathrm{C}$, and 
a different sample was used for each analysis. The running time was set at $6 \mathrm{~min}, 0-2 \mathrm{~min}$ for increasing rotation rate, 2-4 min for decreasing rotation rate and 4-6 min for increasing speed. The first ramp was used to break thixotropy. Before each analysis, the samples were stored at rest for $10 \mathrm{~min}$ for the uniformity of temperature. To adjust the experimental data, the rheological models of Ostwald-De Waele (Power Law), Casson and Herschel-Bulkley were tested, using equations 1, 2 and 3, respectively (TEIXEIRA, OLIVEIRA \& RAMOS, 2013):

$$
\begin{gathered}
\tau=K \cdot \dot{\gamma}^{n} \\
\tau^{0,5}=K_{0 C}+K_{C} \cdot \dot{\gamma}^{0,5} \\
\tau=\tau_{0}+K_{H} \cdot \dot{\gamma}^{n_{H}}
\end{gathered}
$$

Where:

$\tau=$ the shear stress $(\mathrm{Pa}) ; \quad \dot{\gamma}=$ the strain rate $\left(\mathrm{s}^{-1}\right) ; K$ and $K_{H}=$ consistency indices $(\mathrm{Pa} \mathrm{s})$; $K_{C}=$ the Casson plastic viscosity $(\mathrm{Pa} . \mathrm{s})^{1 / 2} ; \tau_{0}$ and $K_{0 C}=$ the initial shear stress for the HershelBulkley $(\mathrm{Pa})$ and Casson $(\mathrm{Pa})^{1 / 2}$ models; $n$ and $n_{H}=$ flow behavior rates (adimensional) (TEIXEIRA, OLIVEIRA \& RAMOS, 2013).

To adjust the models to the experimental data, the $S A S^{\circledR}$ statistical software system was used, version 9.1, licensed to the Universidade Federal de Viçosa (SAS, 2008). The quality of the adjustment of the model was verified by the level of significance of the coefficients $(p)$, lack of adjustment and coefficient of determination $\left(R^{2}\right)$.

\subsection{EFFECT OF TEMPERATURE}

The effect of temperature on apparent viscosity, at a specific strain rate, was analyzed by adjusting the Arrhenius equation (Equation 4) to the experimental data (TEIXEIRA, OLIVEIRA \& RAMOS, 2013):

$$
\eta_{a}=\eta_{\infty} \times \exp \left(E_{a} / R T\right)
$$

Where:

$\eta_{a}=$ the apparent viscosity (mPa.s); $\eta_{\infty}=$ an empirical constant (mPa.s); $E_{a}=$ the activation energy of the flow $\left(\mathrm{kJ} \mathrm{mol}^{-1}\right) ; R=$ the ideal gas constant $\left(8,314.10^{-3} \mathrm{~kJ} \mathrm{~mol}^{-1} \mathrm{k}^{-1}\right)$ and $T=$ the temperature in absolute scale $(\mathrm{K})$.

\subsection{VISCOELASTIC PROPERTIRES}

The oscillatory tests were performed in a controlled stress rheometer (MARS HAAKE, Thermo Corp. Electroma, Germany) at a temperature of $25 \pm 0.2{ }^{\circ} \mathrm{C}$, using a concentric cylinder sensor of $20 \mathrm{~mm}$ in diameter (Z20 DIN). First, shear stress probe was carried out at the range of 1 to $25 \mathrm{~Pa}$, at a frequency of $0.1 \mathrm{~Hz}$, to determine the linear viscoelasticity range. Later, oscillatory tests were carried out with frequency scanning from 0.1 to $10 \mathrm{~Hz}$, which occurred within the linear viscoelasticity region. The parameters storage modulus ( $G$ '), loss modulus ( $G$ ") and complex viscosity $\left(\eta^{*}\right)$ were determined and statistically analyzed (SATO \& CUNHA, 2007; HAMINIUK et al., 2009).

\subsection{STATISTICAL ANALYSIS}

The statistical analyses were performed using the SAS statistical software system (SAS, 2008), version 9.1, licensed to the Universidade Federal de Viçosa (Brazil). 


\subsection{FLOW CURVES}

The rheological behaviors of different samples of sweetened condensed milk at temperatures of 5 and $25^{\circ} \mathrm{C}$ are shown in Figure 1. Similar behaviors were observed for all temperatures. The rheological parameters of the models of Casson and Ostwald-De Waele (PowerLaw), to describe the experimental data obtained are presented in Tables 1 and 2.

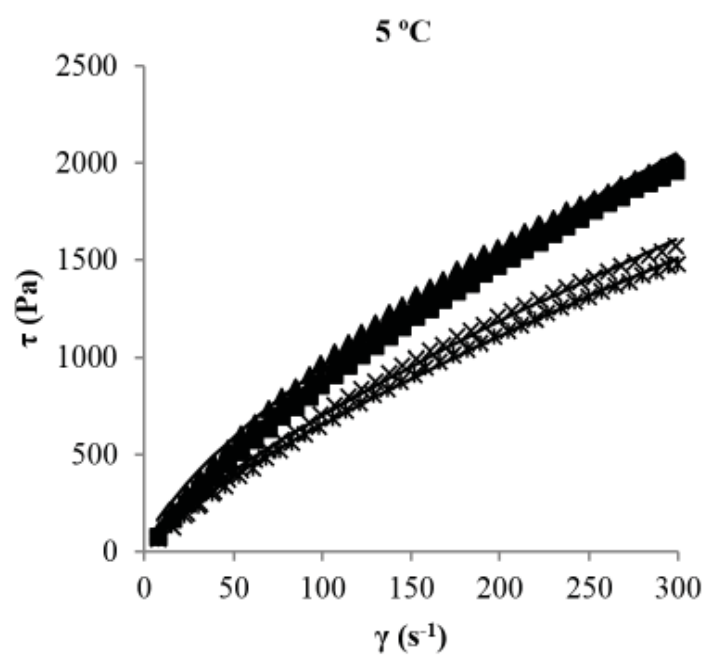

$\bullet \mathrm{A} \backsim \mathrm{B} \Delta \mathrm{C} \times \mathrm{E} * \mathrm{D}$

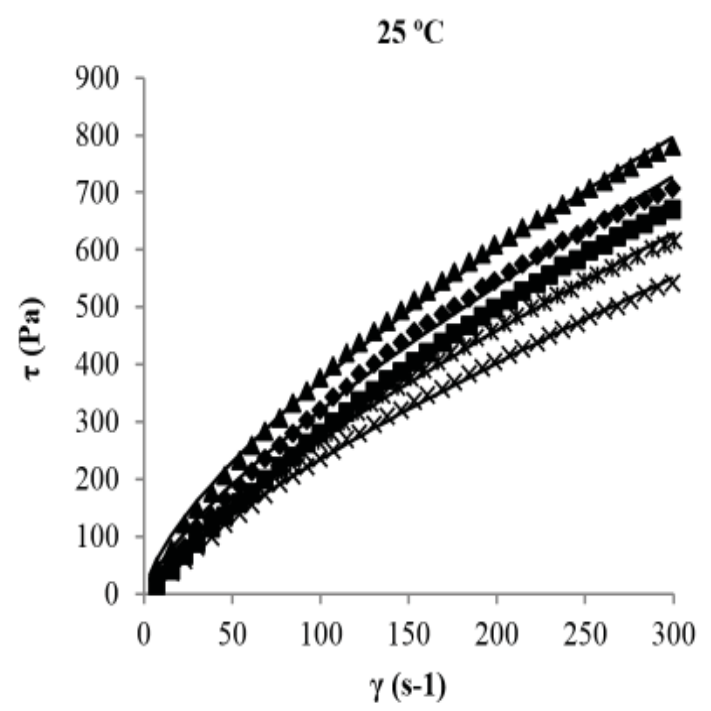

- $\mathrm{A} \boldsymbol{\nabla} \boldsymbol{\Delta} \mathrm{C} \times \mathrm{E} * \mathrm{D}$

\section{FIGURE1-EXPERIMENTALDATAOFSHEARSTRESSVERSUSSTRAINRATEFORTHEDIFFERENT SAMPLES OF SWEETENED CONDENSED MILK AT TEMPERATURES OF 5 AND $25^{\circ} \mathrm{C}$, AND ESTIMATE BY THE POWER LAW MODEL}

The Herschel-Bulkley model was not well adjusted to the experimental data and, therefore, was not considered in the discussion of the results. The power law model presented the best adjustment to the experimental data for all treatments $\left(R^{2} \geq 0.996\right)$, although this model does not 
consider the yield stress, which is a very important rheological property. It was also found that samples of sweetened condensed milk showed pseudoplastic fluid behavior for all temperatures studied $(0.67 \leq n \leq 0.94)$ (Table 1$)$, which can be seen in Figure 1. Such behavior is related to the high concentration of solids, (72\%), in the product (FLAUZINO, 2007; VÉLEZ-RUIZ \& BARBOSACÁNOVAS, 1998). Pseudoplastic behavior has also been observed in other types of products, such as whole pulp of guava, cashew (FERREIRA et al., 2002), jabuticaba (Myrcia cauliflora Berg.) (SATO \& CUNHA, 2007), and mango (VIDAL, GASPARETTO \& GRANDIN, 2000), mustard (JUSZCZAK et al., 2004), pummelo juice concentrates (CHIN et al., 2009), blueberry pulp with different concentrations of xanthan gum and fructose (KECHINSKI et al., 2011), as well as suspensions of nanoparticles in aqueous solution (HOJJAT et al., 2011), among others. However, research works involving the rheology of concentrated dairy products, such as sweetened condensed milk, are still scarce.

TABLE 1 -PARAMETERS OF THEPOWER LAW MODELFOR SWEETENED CONDENSED MILKOF DIFFERENT BRANDS AND AT TEMPERATURES RANGING FROM 5 TO $55^{\circ} \mathrm{C}$

\begin{tabular}{c|c|c|c|c|c|c|c}
\hline \multirow{2}{*}{ Brand } & \multirow{2}{*}{ Parameter $^{1}$} & \multicolumn{7}{|c}{ Temperature $\left({ }^{\circ} \mathbf{C}\right)$} \\
\cline { 3 - 7 } & & $\mathbf{5}$ & $\mathbf{1 5}$ & $\mathbf{2 5}$ & $\mathbf{3 5}$ & $\mathbf{4 5}$ & $\mathbf{5 5}$ \\
\hline \multirow{3}{*}{$\mathrm{A}$} & $\mathrm{K}$ & 27.60 & 16.53 & 10.25 & 5.69 & 2.82 & 1.82 \\
& $\mathrm{n}$ & 0.75 & 0.74 & 0.75 & 0.77 & 0.82 & 0.84 \\
& $\mathrm{R}^{2}$ & 0.999 & 0.997 & 0.996 & 0.997 & 0.997 & 0.999 \\
\hline \multirow{3}{*}{$\mathrm{B}$} & $\mathrm{K}$ & 23.77 & 15.27 & 6.31 & 3.21 & 1.81 & 0.70 \\
& $\mathrm{n}$ & 0.78 & 0.76 & 0.82 & 0.86 & 0.89 & 0.94 \\
& $\mathrm{R}^{2}$ & 0.999 & 0.997 & 0.998 & 0.998 & 0.998 & 0.996 \\
\hline \multirow{3}{*}{$\mathrm{C}$} & $\mathrm{K}$ & 39.00 & 27.35 & 15.30 & 5.27 & 4.75 & 1.48 \\
& $\mathrm{n}$ & 0.67 & 0.67 & 0.69 & 0.78 & 0.71 & 0.85 \\
& $\mathrm{R}^{2}$ & 0.998 & 0.997 & 0.998 & 0.998 & 0.998 & 0.999 \\
\hline \multirow{3}{*}{$\mathrm{D}$} & $\mathrm{K}$ & 19.79 & 13.71 & 7.57 & 4.35 & 2.76 & 2.34 \\
& $\mathrm{n}$ & 0.76 & 0.75 & 0.77 & 0.78 & 0.79 & 0.75 \\
& $\mathrm{R}^{2}$ & 0.999 & 0.998 & 0.998 & 0.998 & 0.999 & 0.999 \\
\hline \multirow{3}{*}{$\mathrm{E}$} & $\mathrm{K}$ & 21.72 & 13.62 & 6.55 & 3.04 & 1.57 & 0.67 \\
& $\mathrm{n}$ & 0.75 & 0.74 & 0.78 & 0.83 & 0.87 & 0.93 \\
& $\mathrm{R}^{2}$ & 0.998 & 0.998 & 0.998 & 0.998 & 0.998 & 0.996 \\
\hline
\end{tabular}

${ }^{1}$ Parameter $=\mathrm{K}$ - consistency index $(\mathrm{Pa} \mathrm{sn}) ; \mathrm{n}$ - the flow behavior index; $\mathrm{R}^{2}$ - coefficient of determination.

The consistency index values determined were higher than those found by Flauzino (2007), for sweetened condensed milk analyzed a 10 days after manufacture, at different temperatures, with strain rate ranging from 0.1 to $100 \mathrm{~s}^{-1}$, which found values of 12.57 and $2.76 \mathrm{~Pa} . \mathrm{s}^{\mathrm{n}}$ at 5 and $25^{\circ} \mathrm{C}$, respectively. The values of the flow behavior index obtained by this research were also different $(0.99$ at $25^{\circ} \mathrm{C}$ ). However, a likely cause for this variation is the time of manufacture of the products analyzed, since casein molecules tend to aggregate, forming a three-dimensional net, leading to an increased viscosity of sweetened condensed milk as storage time increases (VARNAM \& SUTHERLAND, 1994). A better adjustment of the power law model was also observed by Juszczak et al. (2004), for commercial mustards at $25^{\circ} \mathrm{C}$, and Vélez-Ruiz and Barbosa-Cánovas (1998) for concentrated milk, stored for three weeks, with total solid content between 19.6 and $30.5 \%$ at temperatures ranging from 15 to $25{ }^{\circ} \mathrm{C}$. Despite the better adjustment of the power law model, Casson model, which considers the yield stress, also showed good adjustment to the experimental data $\left(R^{2} \geq 0.989\right)$. Thus, this model can also be used to explain the rheological behavior of sweetened condensed milk under the conditions employed in this study. 
TABLE 2 - PARAMETERS OF THE CASSON MODEL FOR SWEETENED CONDENSED MILK OF DIFFERENT BRANDS AND AT TEMPERATURES RANGING FROM 5 TO $55^{\circ} \mathrm{C}$

\begin{tabular}{c|c|c|c|c|c|c|c}
\hline \multirow{2}{*}{ Brand } & \multirow{2}{*}{ Parameter } & \multicolumn{7}{|c}{ Temperature $\left.{ }^{\circ} \mathrm{C}\right)$} \\
\cline { 3 - 7 } & & $\mathbf{5}$ & $\mathbf{1 5}$ & $\mathbf{2 5}$ & $\mathbf{3 5}$ & $\mathbf{4 5}$ & $\mathbf{5 5}$ \\
\hline \multirow{3}{*}{$\mathrm{A}$} & $\mathrm{K}_{0}$ & 7.66 & 5.98 & 4.63 & 3.29 & 2.01 & 1.58 \\
& $\mathrm{~K}_{\mathrm{c}}$ & 2.19 & 1.60 & 1.31 & 1.08 & 0.91 & 0.76 \\
& $\mathrm{R}^{2}$ & 0.995 & 0.991 & 0.989 & 0.992 & 0.994 & 0.996 \\
\hline \multirow{3}{*}{$\mathrm{B}$} & $\mathrm{K}_{0}$ & 6.76 & 5.50 & 3.05 & 1.89 & 1.15 & 0.33 \\
& $\mathrm{~K}_{\mathrm{c}}$ & 2.21 & 1.67 & 1.35 & 1.09 & 0.92 & 0.70 \\
& $\mathrm{R}^{2}$ & 0.996 & 0.992 & 0.995 & 0.995 & 0.997 & 0.995 \\
\hline \multirow{3}{*}{$\mathrm{C}$} & $\mathrm{K}_{0}$ & 9.54 & 8.08 & 5.99 & 3.14 & 3.29 & 1.32 \\
& $\mathrm{~K}_{\mathrm{c}}$ & 2.09 & 1.61 & 1.30 & 1.05 & 0.79 & 0.73 \\
& $\mathrm{R}^{2}$ & 0.991 & 0.989 & 0.992 & 0.995 & 0.994 & 0.997 \\
\hline \multirow{3}{*}{$\mathrm{D}$} & $\mathrm{K}_{0}$ & 6.43 & 5.42 & 3.80 & 2.89 & 2.27 & 2.25 \\
& $\mathrm{~K}_{\mathrm{c}}$ & 1.89 & 1.50 & 1.24 & 0.95 & 0.78 & 0.63 \\
& $\mathrm{R}^{2}$ & 0.995 & 0.992 & 0.994 & 0.995 & 0.996 & 0.996 \\
\hline \multirow{3}{*}{$\mathrm{E}$} & $\mathrm{K}_{0}$ & 6.71 & 5.44 & 3.53 & 2.07 & 1.24 & 0.45 \\
& $\mathrm{~K}_{\mathrm{c}}$ & 1.95 & 1.46 & 1.16 & 0.96 & 0.81 & 0.65 \\
& $\mathrm{R}^{2}$ & 0.992 & 0.992 & 0.994 & 0.995 & 0.996 & 0.995 \\
\hline
\end{tabular}

${ }^{1}$ Parameter $=\mathrm{K} 0$ - initial tension $(\mathrm{Pa}) 1 / 2 ; \mathrm{Kc}$ - Casson plastic viscosity $(\mathrm{Pa} \mathrm{s}) 1 / 2 ; \mathrm{R}^{2}$ - coefficient of determination

The comparison of different brands, at the same temperature, using the power law model, showed that the sweetened condensed milk of brand $C$ presented, in general, the highest values of consistency index $(\mathrm{K})$, and followed by the brand $\mathrm{A}$. The products of brands $\mathrm{B}, \mathrm{D}$ and $\mathrm{E}$ had the lowest values of $\mathrm{K}$ (Table 1). Since the quality of these products is largely related to consistency, significant differences in their quality can be observed when different brands of sweetened condensed milk found in the market are compared. Using the Casson model, it can be noticed that the brands $C$ and $A$ also showed the highest values of the yield stress $\left(K_{0}\right)$, followed by the others (Table 2). On the other hand, no major differences were observed among the products (Table 2 ) for the values of plastic viscosity $\left(\mathrm{K}_{\mathrm{c}}\right)$.

\subsection{EFFECT OF TEMPERATURE}

The flow behavior index $(\mathrm{n})$ of the products was slightly influenced by temperatures ranging from 5 to $25^{\circ} \mathrm{C}$. However, the $\mathrm{n}$ values increased (behavior closer to the Newtonian behavior) at temperatures from 35 to $55{ }^{\circ} \mathrm{C}$. On the other hand, the consistency index $(\mathrm{K})$ of the products decreased as temperature increased throughout the range studied (Table 1). Similarly, the Casson model parameters $\left(\mathrm{K}_{\mathrm{o}}\right.$ and $\mathrm{K}_{\mathrm{c}}$ ) also decreased with increasing temperature (Table 2). It is important to note that, for low temperatures, the initial shear stress values determined by the Casson model were considerably higher than those determined at higher temperatures. Given the importance of this rheological parameter, the Casson model can be considered more appropriate to explain the rheological behavior of sweetened condensed milk at low temperatures ( 5 to $25^{\circ} \mathrm{C}$ ), and the power law model, for higher temperatures, considering, under those circumstances, the values of initial shear stress is negligible. The power law model is more advantageous than the others because it is simpler and easier to be worked.

To better quantify the effect of temperature on the rheological characteristics of products, the Arrhenius model was adjusted to the experimental data of apparent viscosity $\left(\eta_{a p}\right)$, calculated 
from the power law model for the shear rate of $100 \mathrm{~s}^{-1}$. The Arrhenius model parameters and the effect of temperature on apparent viscosity are shown in Table 3 and Figure 2, respectively.

TABLE 3 - PARAMETERS OF THE ARRHENIUS MODEL FOR THE DIFFERENT SAMPLES OF SWEETENED CONDENSED MILK FOR THE STRAIN RATE OF $100 \mathrm{~s}^{-1}$

\begin{tabular}{c|c|c|c|c|c}
\hline \multirow{2}{*}{$\begin{array}{c}\text { Arrhenius } \\
\text { Parameter }\end{array}$} & \multicolumn{5}{|c}{ Sample } \\
\cline { 2 - 6 } & A & B & C & D & E \\
\hline$\eta_{\infty} \times 10^{-3}(\mathrm{mPa} s)$ & 1.948 & 0.185 & 0.474 & 3.028 & 0.229 \\
$\mathrm{E}_{\mathrm{a}}\left(\mathrm{kJ} \mathrm{mol}^{-1}\right)$ & 35.43 & 40.94 & 39.08 & 33.82 & 39.96 \\
$\mathrm{R}^{2}$ & 0.999 & 0.993 & 0.994 & 0.997 & 0.998 \\
Equation $(\mathrm{y}=\mathrm{ax}+\mathrm{b})$ & $4262 . \mathrm{x}-6.24$ & $4924 . x-8.58$ & $4701 . x-7.66$ & $4068 . \mathrm{x}-5.80$ & $4806 \mathrm{x}-8.38$ \\
\hline
\end{tabular}

${ }^{1} \eta^{\infty}$ - empirical constant, Ea - activation energy to flow, $R^{2}$ - coefficient of determination.

The Arrhenius model presented good adjustment to the experimental data of apparent viscosity, according to temperature for all samples, with coefficients of determination ranging from 0.992 to 0.999 .

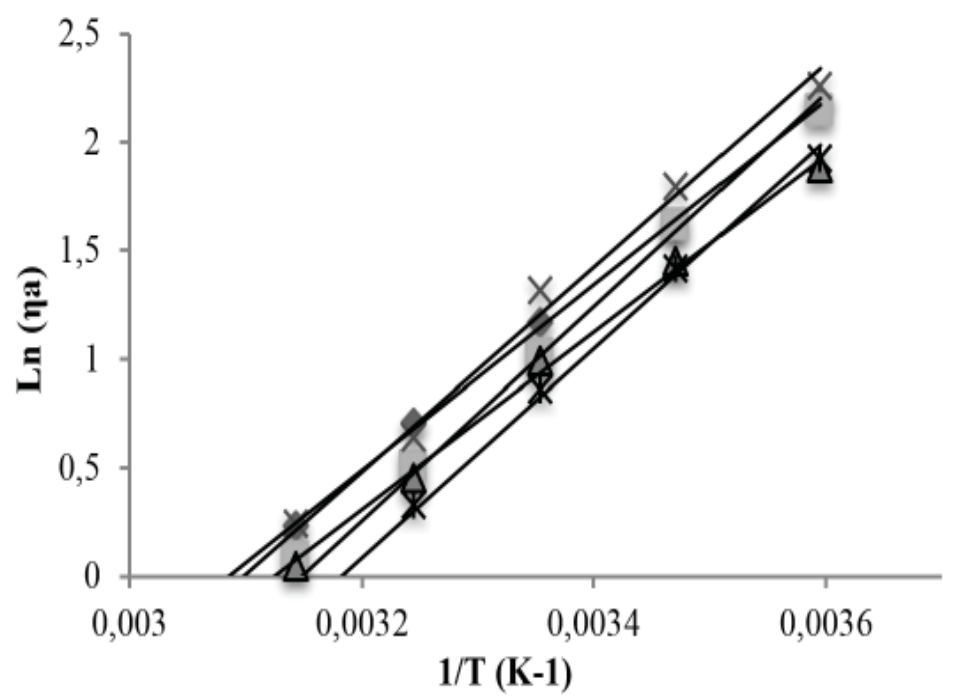

$\rightarrow \mathrm{A} \quad \mathrm{B} \quad \times \mathrm{C} \quad \Delta \mathrm{D} \quad * \mathrm{E}$

FIGURE 2 - EFFECT OF TEMPERATURE ON THE APPARENT VISCOSITY OF THE SAMPLES OF CONDENSED MILK. ADJUSTMENT OF THE EXPERIMENTAL DATA TO THE ARRHENIUS MODEL

The magnitude of the flow activation energy $\left(E_{a}\right)$ reveals that viscosity depends on temperature (FERREIRA, GUIMARÃES \& MAIA, 2008). According to Steffe (1996), the higher the value of $E_{a}$, the greater the sensitivity of a system to changes in temperature. Therefore, it was observed that the products of brands $B, C$ and $E$ presented the highest sensitivity to changes in temperature, followed by brands $A$ and $D$ (Table 3 ). At the temperature of $5^{\circ} \mathrm{C}$, the product of brands $\mathrm{B}$ and $\mathrm{E}$ showed apparent viscosity of 8504 and $7012 \mathrm{mPa}$.s, respectively, and, at $55^{\circ} \mathrm{C}$, the values were 539 and $492 \mathrm{mPa}$.s. It indicates reduction by approximately $93.3 \%$ in the apparent viscosity. The product of brand $\mathrm{D}$ presented the lowest variation $(88.5 \%)$. This smaller variation corresponds 
to the lowest value of flow activation energy $\left(E_{a}\right)$ and highest value of the empirical constant $\left(\eta_{\infty}\right)$, as observed in Table 3. The $\mathrm{E}_{\mathrm{a}}$ values determined in this study were lower than those reported by Flauzino (2007) for sweetened condensed milk (53.06 kJ mol-1). Vélez-Ruiz \& Barbosa-Cánovas (1998) found $E_{a}$ values of 37.5 and $44.7 \mathrm{~kJ} \mathrm{~mol}^{-1}$ for concentrated milk to $42.4 \%$ of total solids and stored for two to three weeks, respectively.

\subsection{VISCOELASTIC PROPERTIES}

The shear stress probe demonstrated that the linear viscoelastic region for the different samples of sweetened condensed milk ranged from 2.0 to $10.5 \mathrm{~Pa}$. Thus, after knowing the linear viscoelastic region of each sample, the values of storage modulus (G') and loss modulus (G") were determined according to frequency and are presented in Figure 3.

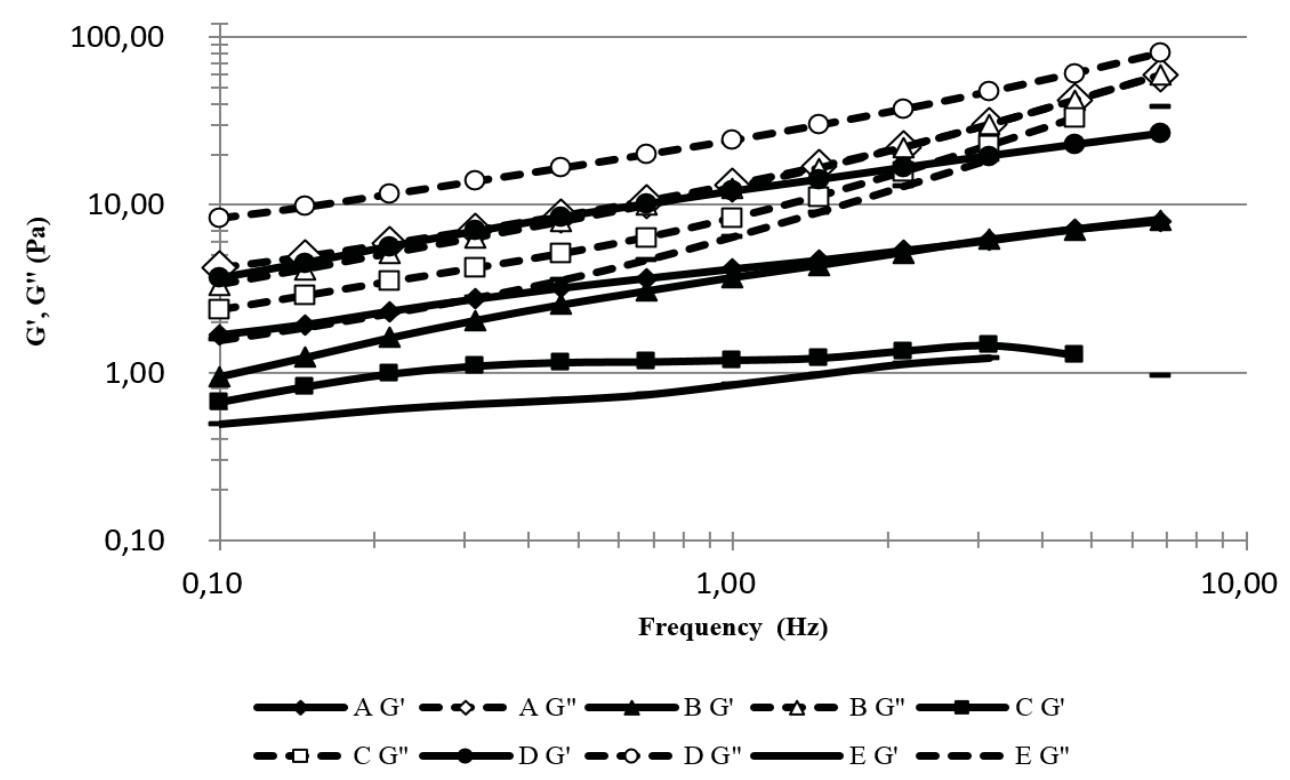

FIGURE 3 - VALUES OF STORAGE MODULUS (G') AND LOSS MODULUS (G'), ACCORDING TO FREQUENCY AT $25^{\circ} \mathrm{C}$

G'- Filled Markers, G"'- Hollow Markers.

It was observed that, at this frequency range, the values of loss modulus ( $G$ ") were higher than those of the storage modulus (G') for all samples studied (Figure 3), with G'/G' ratio ranging from 2.0 to 55.4, and this ratio tends to increase as frequency increases, since variation in loss modulus increases with increasing frequency.

If G' value is higher than G" value, the food material has the characteristic of a semi-solid, i.e., it is more elastic than viscous. On the other hand, if G" > G', the material behaves as a semi-liquid and the energy used in the deformation of the material is associated with viscous dissipation (RAMOS \& IBARZ, 2006). Therefore, it was observed that the sweetened condensed milk can be considered a semi-liquid product, with a more viscous than elastic behavior, and this viscous characteristic tends to increase at higher frequencies (Figure 3). The comparison of the studied samples revealed that the product of brand D presented the highest values of G" and G', while that of the brand C, the lowest. These products also presented the lowest and highest G'/G' ratios, respectively. The values of G', G' and $\left|\eta^{*}\right|$, determined at the frequency of $1 \mathrm{~Hz}$, are presented in Table 4.

It was observed that the sweetened condensed milk of brand $D$ presented the highest values of $G^{\prime}, G^{\prime \prime}$ and $\left|\eta^{*}\right|$, differing significantly from the others $(p<0.05)$. The lowest values were observed in the product of brand $E$ (Table 4). 


\section{TABLE 4 - VALUES OF STORAGE MODULUS (G'), LOSS MODULUS (G”) AND COMPLEX VISCOSITY $\left|\eta^{*}\right|$ DETERMINED AT 1 HZ FOR THE DIFFERENT SAMPLES OF CONDENSED MILK}

\begin{tabular}{cccc}
\hline Sample & G' $^{\prime}(\mathbf{P a})$ & $\mathbf{G}^{\prime \prime}(\mathbf{P a})$ & $\left|\boldsymbol{\eta}^{\star}\right|(\mathbf{P a} \mathbf{~ s})$ \\
\hline A & $4.15^{\mathrm{b}}$ & $13.17^{\mathrm{b}}$ & $2.20^{\mathrm{b}}$ \\
B & $3.67^{\mathrm{b}}$ & $12.69^{\mathrm{b}}$ & $2.10^{\mathrm{b} . \mathrm{c}}$ \\
C & $1.18^{\mathrm{b}}$ & $8.35^{\mathrm{b} . \mathrm{c}}$ & $1.34^{\mathrm{b} . \mathrm{c}}$ \\
D & $12.09^{\mathrm{a}}$ & $24.32^{\mathrm{a}}$ & $4.33^{\mathrm{a}}$ \\
E & $0.82^{\mathrm{b}}$ & $6.36^{\mathrm{c}}$ & $1.02^{\mathrm{c}}$ \\
\hline
\end{tabular}

a-c Means within a column with different superscripts differ $(P<0.05)$ by Tukey test.

\section{CONCLUSION}

The Power Law and Casson models can be used to explain the rheological behavior of the products, which presented pseudoplastic fluid behaviors. The effect of temperature on apparent viscosity of the products followed the Arrhenius model, with activation energy values ranging from 33.8 to $40.9 \mathrm{~kJ}^{\mathrm{mol}}{ }^{-1}$. Sweetened condensed milk of different brands showed behavior that characterizes a semi-liquid (G"> G') material. The magnitude of these rheological properties seems to be related with the levels of proteins and lipids in the product.

\section{RESUMO \\ CARACTERIZAÇÃO REOLÓGICA DE LEITE CONDENSADO COMERCIAL}

Neste estudo foram analisadas amostras de leite condensado de cinco marcas comerciais, representativas do mercado brasileiro, quanto ao comportamento reológico e viscoelasticidade. Os produtos apresentaram comportamento de fluido pseudoplástico, com os dados experimentais de tensão de cisalhamento versus taxa de deformação demonstrando bons ajustamentos aos modelos da Lei da Potência e de Casson. Observou-se que o efeito da temperatura sobre a viscosidade aparente dos produtos seguiu o modelo de Arrhenius, com valores de energia de ativação na faixa de $33,8-40,9 \mathrm{~kJ} \mathrm{~mol}^{-1}$. Os produtos apresentaram módulo de perda (G") maior que o módulo de armazenamento (G'), indicando comportamento de material semi-líquido.

PALAVRAS-CHAVE: COMPORTAMENTO REOLÓGICO; VISCOELASTICIDADE; LEITE CONDENSADO.

\section{REFERENCES}

1 AHMED, J.; RAMASWAMY, H.S. Viscoelastic properties of sweet potato puree infant food. Journal of Food Engineering, v.74, p.376-382, 2006

2 BIENVENUE, A.; JIMÉNEZ-FLORES, R.; SINGH, H. Rheological properties of concentrated skim milk: importance of soluble minerals in the changes in viscosity during storage. Journal of Dairy Science, v.86, p.3813-3821, 2003.

3 CHIN, N.L.; CHAN, S.M.; YUSOF, Y. A.; CHUAH, T.G.; TALIB, R.A. Modeling of rheological behavior of pummelo juice concentrates using master-curve. Journal of Food Engineering, v.93, p.134-140, 2009.

4 FAO/WHO. Food and Agricutural Organization/World Heath Organization. Codex Alimentarius. Standard for sweetened condensed milks (CODEX STAN A-4-1971) Available at: http://www.codexalimentarius.net/web/standard_list.jsp Access on: May 31, 2012.

5 FERREIRA, G.M.; GUIMARÃES, M.J.O.C.; MAIA, M.C.A. Efeito da temperatura e taxa de cisalhamento nas propriedades de escoamento da polpa de cupuaçu (T. grandiflorum Schum) integral. Revista Brasileira de Fruticultura, v.30, p.385-389, 2008 
6 FERREIRA, G.M.; QUEIROZ, A.J.M.; CONCEIÇÃO, R.S.; GASPARETTO, C.A. Efeito da temperatura no comportamento reológico das polpas de caju e goiaba. Revista Ciências Exatas e Naturais, v.4, p.175-184, 2002.

7 FLAUZINO, R.D Influência da temperatura e do teor de gordura nos parâmetros reológicos do leite condensado e creme de leite. 2007. 99 f. Dissertação (Mestrado em Engenharia e Ciência de Alimentos) Instituto de Biociências, Letras e Ciências Exatas, Universidade Estadual Paulista, São José do Rio Preto, 2007.

8 GUNASEKARAN, S.; AK, M.M. Dynamic oscillatory shear testing of foods-selected applications. Trends in Food Science and Technology, v.11, p.115-127, 2000.

9 HAMINIUK, C.W.I.; SIERAKOWSKI, M.R.; IZIDORO, D.R.; MACIEL, G.M.; SCHEER, A.P.; MASSON, M.L. Comportamento reológico de sistemas pécticos de polpas de frutas vermelhas. Ciência e Tecnologia de Alimentos, v.29, n.1, p.225231, 2009.

10 HOJJAT, M.; ETEMAD, S.G.; BAGHERI, R.; THIBAULT, J. Rheological characteristics of non-Newtonian nanofluids: experimental investigation. International Communications in Heat and Mass Transfer, v.38, p.144-148, 2011.

11 JUSZCZAK, L.; WITCZAK, M.; FORTUNA, T.; BANYS, A. Rheological properties of commercial mustards. Journal of Food Engineering, v.63, p.209-217, 2004.

12 KECHINSKI, C.P.; SCHUMACHER, A.B.; MARCZAK, L.D.F.; TESSARO, I.C.; CARDOZO, N.S.M. Rheological behavior of blueberry (Vaccinium ashei) purees containing xanthan gum and fructose as ingredients. Food Hydrocolloids, v.25, p.299-306, 2011.

13 OZER, B.H.; BELL, A.E.; GRANDISON, A.S.; ROBINSON, R.K. Rheological properties of concentrated yoghurt (LABNEH). Journal of Texture Studies, v.29, p.67-79, 1998

14 RAMOS,A.M.; IBARZ, A. Comportamiento viscoelástico de pulpa de membrillo en función de la concentración de sólidos solubles. Ciência e Tecnologia de Alimentos, v.26, p.214-219, 2006

15 SAS Institute Inc. Statistical Analysis System. CARY, NC, USA, 2008

16 SATO, A.C.K.; CUNHA, R.L. Influência da temperatura no comportamento reológico da polpa de jabuticaba. Ciência e Tecnologia de Alimentos, v.27, p.890-896, 2007

17 SCHRAMM, G. Reologia e reometria: fundamentos teóricos e práticos. São Paulo: Artliber Editora, 2006.240 p.

18 STEFFE, J.F. Rheological methods in food process engineering. $2^{\text {nd }}$ ed. Michigan: Freeman Press, 1996.428 p.

19 TAMIME, A.Y. Dairy powders and concentrated products. Oxford: Blackwell Publishing, 2009.408 p.

20 TEIXEIRA, T.R; OLIVEIRA, A.N.; RAMOS, A.M. Efeitos da temperatura e concentração nas propriedades físicas da polpa de araçá-boi. B. do CEPPA, v.31, n.2, p.275-284, 2013

21 VARNAM, A.H.; SUTHERLAND, J.P. Milk and milk products: technology, chemistry and microbiology. Londres: Chapman \& Hall, 1994. 451 p. (Food Products Series, 1).

22 VÉLEZ-RUIZ, J.F.; BARBOSA-CÁNOVAS, G.V. Rheological properties of concentrated milk as a function of concentration, temperature and storage time. Journal of Food Engineering, v.35, p.177-190, 1998.

23 VIDAL, J.R.M.B.; GASPARETTO, C.A.; GRANDIN, A. Efeito da temperatura no comportamento reológico de polpa de manga. Revista Ciências Exatas e Naturais, v.1, p.69-76, 2000. 